\title{
Pengaruh Resiliensi terhadap Job Insecurity pada Pegawai Honorer
}

\author{
Mochamad Amin Zakaria ${ }^{1}$, Nida Hasanati' ${ }^{2}$ Muhammad Shohib ${ }^{3}$ \\ Fakultas Psikologi, Universitas Muhammadiyah Malang \\ e-mail: ${ }^{1}$ mochamadaminzakaria17@gmail.com, ${ }^{2 n i d a 3105 @ g m a i l . c o m, ~}$ \\ ${ }^{3}$ m.shohib.umm@gmail.com
}

\begin{abstract}
The existence of honorary staff who cannot be appointed as permanent employees is one of the problems that have yet to be resolved. The honorary employees certainly want to get their rights as employees who work to devote themselves to the community. Employees who feel that job security is certainly less able to accept changes in the conditions of the work environment which would make them unable to develop in the work environment. Jobs that are not permanent will create job insecurity conditions. The attitude of employees in facing a change is, of course, different, employees with high resilience can be interpreted as being able to adapt and can change a chaotic environmental condition to solve problems and turn them towards a positive one. The purpose of this study is to see how much influence the resilience of job insecurity has on honorary employees. This research is quantitative research with the number of subjects 129 honorary employees. The method of data collection uses the Job Insecurity Quisionare scale and the CD-RISC scale. Data analysis using a linear regression test. The results showed that $\beta-0.252$ p0,000 note that there was a negative effect on resilience towards job insecurity, which means that the higher the resilience, the lower the job insecurity. Resilience contributed significantly (9.3\%) to job insecurity.
\end{abstract}

KEYWORDS Job insecurity, resilience, honorary employees

CITATION Zakaria, M. A., Hasanati, N., \& Shohib, M. (2019). Pengaruh resiliensi terhadap job insecurity pada pegawai honorer. Cognicia, 7, (3), 346-358.

Honorer adalah pegawai/karyawan honorium yang bekerja di instansi pemerintahan atau swasta dengan persyaratan tertentu yang dinaungi oleh Aparatur Sipil Negara (ASN) dan digaji oleh APBN/APBD setempat (Rakayoga \& Gusti Lanang, 2014). Miftah Thoha (2005) menerangkan bahwa pegawai honorer atau yang biasa disebut pegawai non-PNS adalah salah satu aset sumber daya manusia (SDM) yang sangat berpengaruh kepada perkembangan sebuah organisasi/instansi pemerintahan maupun swasta yang bekerja dalam bidang pelayanan masyarakat seperti Rumah Sakit. Keberadaan tenaga honorer yang tidak dapat diangkat menjadi pegawai tetap setelah diberlakukannya Undang-Undang Nomor 5 Tahun 2014 menjadi tidak jelas.

Jumlah angkatan kerja di Indonesia masih bersifat fluktuatif. Hal tersebut berarti jenis pekerjaan di Indonesia bersifat musiman. Faktor musiman tersebut ditunjukkan dari jumlah karyawan/ pegawai yang berstatus sementara cukup banyak, yaitu sejumlah $40 \%$ dari jumlah keseluruhan (International Labour Organizational, Sukmaningrum, 2018). Dilansir dari detik.com pada hari Kamis, 4 Oktober 2018, 
menurut Kementerian Pendayagunaan Aparatur Negara dan Reformasi Birokrasi (KemenpanRB) data pemerintah jumlah PNS saat ini mencapai 4,3 juta orang dan pemerintah telah mengangkat 1,1 juta pegawai honorer menjadi PNS tanpa tes, jumlah itu merupakan 25\% dari keseluruhan PNS yang ada di Indonesia, dalam hal ini banyak sekali pegawai honorer yang mengabdi bertahun-tahun tetapi tidak kunjung diangkat menjadi pegawai tetap dan pastinya pegawai honorer sendiri ingin mendapatkan kejelasan akan status kepegawaiannya.

Semakin banyaknya pekerja semakin ketat pula persaingan di dalam sebuah organisasi/instansi, peneliti berasumsi bahwa pegawai honorer di Rumah Sakit kurang mendapatkan perlakuan yang baik dari instansi seperti tindak diskriminasi dan banyak pegawai honorer yang telah mengabdi belasan tahun lamanya, karena kebijakan pemerintah yang menyatakan bahwa calon PNS harus memenuhi persyaratan yang telah ditetapkan mengenai umur yaitu maksimal 35 tahun. Para pegawai honorer pastinya ingin mendapatkan fasilitas-fasilitas yang nyaman dan aman untuk menunjang pekerjaannya. Di sisi lain pastinya para pegawai honorer ingin tetap bekerja pada instansi dimana mereka mengabdi, akan tetapi pada sisi lainnya meraka merasa terancam atau senatiasa khawatir pada posisi dimana mereka bekerja (Andrinirina, 2015).

Hal ini memberi gambaran bahwa kondisi sebuah pekerjaan bisa saja menjadi berubah tanpa mereka sadari. Kondisi tersebut dapat membuat pegawai merasa tidak aman dan memungkinkan pegawai memiliki keinginan untuk berpindah. Bukti empiris menunjukan bahwa pekerja non permanen memiliki tingkat job insecurity yang lebih tinggi daripada pekerja tetap (De Witte \& Naswall, 2003). Job Insecurity adalah salah satu kondisi dimana pegawai merasa tidak berdaya dalam mempertahankan kesinambungan yang diinginkan dalam situasi kerja yang mengancam. Kondisi ini secara umum dapat dirasakan oleh semua pekerja, apalagi semakin banyaknya pengangguran dan minimnya lapangan pekerjaan sangat memungkinkan pegawai/karyawan mengalami job insecurity. Job insecurity diukur berdasarkan komponen-komponen yang dikemukakan oleh (Greenhalgh dan Rosenblatt \& Ashford, et al. dalam Pasewark dan Strawser, (1996) yaitu, (1) tingkat pentingnya aspek-aspek pekerjaan yang dirasakan individu, (2) Kemungkinan perubahan negatif pada aspek-aspek pekerjaan yang dirasakan individu, (3) Tingkat kepentingan yang dirasakan individu mengenai potensi setiap peristiwa yang secara negatif dapat mempengaruhi keseluruhan kerja individu, (4) Kemungkinan munculnya peristiwa-peristiwa tersebut yang secara negatif dapat mempengaruhi keseluruhan kerja individu, (5) Ketidakberdayaan yang dirasakan individu. Job insecurity memiliki batasan-batasan tekanan yang masih dapat ditoleransi, tetapi bila melampaui batas daya tahan seseorang maka akan mengakibatkan kerusakan penyimpangan-penyimpangan fisiologis dan psikologis serta menyebabkan hubungan yang tidak harmonis pada orang-orang yang terlibat dalam organisasi.

Pasewark dan Strawser (1996) mengemukakan bahwa kondisi job insecurity mempengaruhi kepuasan kerja, komitmen organisasi dan kepercayaan organisasional yang pada akhirnya mempunyai hubungan dengan keinginan berpindah (turnover). Hal ini sangat mungkin terjadi kepada pegawai/karyawan yang memiliki masa kerja yang tidak dapat ditentukan oleh para pekerjanya. 
Ada beberapa faktor penyebab terjadinya job insecurity, Greenhalgh dan Rosenblath (1984) menjelaskan job insecurity dapat dipengaruhi tiga faktor yaitu, lingkungan kerja, kondisi diluar lingkungan kerja, dan diri pribadi. Faktor job insecurity yang bersumber dari diri pribadi individu adalah yang berkembang dengan kepribadian individu itu sendiri. Pegawai yang memiliki job insecurity pastinya rentan terkena stres, karena masalah yang dihadapi yang berhubungan pada hilangnya pekerjaan, ketegangan mental dan kebingungan terkait masa depan pekerjaannya pada instansi di tempat mereka bekerja (Yashoglu et al, 2013).

Setiap individu dalam menghadapi suatu perubahan kondisi dalam lingkungan kerja yang dapat mengancam pekerjaannya pastinya berbeda-beda. Beberapa orang akan terganggu dengan hal itu, namun yang lain bisa menjadikan suatu keadaan yang menurut mereka mengganggu kearah yang positif, sehingga tidak membuat performa kerja mereka menurun. Kemampuan individu dalam menanggapi sebuah situasi/kondisi yang menurut mereka mengancam dan berusaha untuk keluar dari kondisi tersebut dan memecahkan masalahnya disebut dengan resiliensi.

Grotberg (1999), menjelaskan bahwa resiliensi memiliki arti yaitu sebuah kemampuan individu dalam menghadapi sebuah tekanan dan dapat merubah peristiwa yang buruk menjadikan sebuah pengalaman yang bisa membuat ke arah hidup yang positif. Resiliensi memiliki pengaruh terhadap semua aspek pekerjaan, resiliensi sendiri adalah sebuah kemampuan individu untuk dapat bangkit dari kondisi yang sulit (Listyanti, 2012). Resiliensi sendiri memiliki hubungan dengan OCB (Organizational Citizenship Behavior) atau perilaku karyawan di luar uraian tugas yang dapat memberikan sebuah kontribusi positif bagi perusahan/instansi. Semakin tinggi resiliensi yang dimiliki sesorang maka semakin tinggi $O C B$, dan juga sebaliknya jika semakin redah resiliensi seseorang maka semakin rendah OCB (Yuniar, et al. 2011).

Resiliensi memiliki dua faktor yang berhubungan dengan kecemasan, yaitu kompetensi diri, yaitu rasa percaya diri dan optimis, cepat dalam mengambil keputusan dan fokus mencari solusi permasalahan. (Bitsika et al, 2010) berpendapat bahwa mengembangkan rasa percaya diri dan sikap optimis ketika menghadapi sebuah permasalahan dan fokus untuk mencari solusi bisa mengurangi perasaan cemas pada individu. (Dipayanti \& Chairani, 2012), resiliensi yang dimiliki individu memiliki beberapa faktor yaitu faktor internal dan eksternal, faktor ini seringkali disebut faktor pelindung (Dewanti \& Suprapti, 2014). Faktor pelindung memiliki peran yang sangat penting dalam mengurangi efek negatif lingkungan yang dapat merugikan bagi individu, dan faktor pelindung mempu menguatkan resiliensi pada individu.

Dalam meningkatkan mutu dan kualitas, Rumah Sakit Negeri sebagai instansi pemerintahan yang terjun langsung melayani masyarakat dituntut bekerja secara profesional dan kompeten. Dalam hal ini Pegawai honorer sangat dibutuhkan untuk membantu pekerjaan pegawai tetap (PNS). Pegawai tetap (PNS) dan honorer tidak memiliki perbedaan yang signifikan dalam bekerja, tetapi faktanya pegawai honorer memiliki beban kerja yang lebih seperti, jam kerja lebih panjang dari pegawai tetap, upah yang diberikan tidak sesuai dengan beban kerja, dan terkadang job desk yang diberikan tidak sesuai dengan kemampuan individu. Job desk harusnya berpengaruh 
positif terhadap proses kinerja. Dengan kondisi demikian pegawai honorer dituntut memiliki keterampilan dan tingkat resiliensi yang tinggi.

Penelitian serupa juga telah dilakukan oleh De Cuyper et al, (2008) yang menyatakan bahwa berbagai macam sektor pekerjaan dan macam jabatan pegawai/karyawan dapat menentukan bagaimana pegawai/karyawan mempersepsikan ketahanan kerja dan job insecurity. Pegawai/karyawan sementara identik dengan kondisi ergonomis yang buruk, pendapatan yang lebih rendah, wewenang yang terbatas, dan beban kerja yang lebih tinggi.

Hasil penelitian yang dilakukan oleh Shoss Mindy et al, (2016) yang meneliti tentang pengaruh antar dua studi yaitu resiliensi yang dimiliki karyawan dalam menghapi kondisi job insecurity, mendapatkan hasil bahwa resiliensi memiliki pengaruh ke arah negatif terhadap job insecurity, diketahui bahwa strategi coping menggunakan resiliensi dapat menurunkan perasaan insecure dari karyawan. hal ini dapat dilihat bahwa resiliensi memiliki kontribusi yang positif terhadap turunya perasaan negative dari job insecurity pada karyawan. Berdasarkan dari hasil penelitian sebelumnya, maka peneliti ingin melanjutkan penelitian sebelumnya dengan subjek yang berbeda. Dilihat dari penelitian sebelumnya yang fokus terhadap karyawan perusahaan, disini peneliti ingin berfokus pada pegawai honorer di instansi pemerintahan. Pentingnya penelitian ini dilakukan karena di Indonesia sendiri masih jarang yang meneliti antara resiliensi dan job insecurity. Tujuan dari penelitian ini adalah untuk melihat seberapa besar pengaruh resiliensi terhadap job insecurity.

Manfaat teoritis adalah untuk mengaplikasikan penerapan ilmu psikologi industri dan organisasi. Manfaat praktis dari penelitian ini adalah diharapkan penelitian ini mampu memberikan sebuah informasi baru dan dapat memperluas wawasan dalam ranah psikologi khususnya industri dan organisasi terkait pengaruh resiliensi terhadap job insecurity pada pegawai honorer. Adapun hipotesa dalam penelitian ini yaitu adanya pengaruh negatif resiliensi terhadap job insecurity. Resiliensi tinggi akan mengubah job insecurity menjadi rendah, dan sebaliknya jika resiliensi rendah akan mengubah job insecurity menjadi tinggi.

\section{METODE}

Penelitian yang akan digunakan dalam penelitian ini adalah kuantitatif. Kuantitatif sendiri menurut Sugiyono (2013) adalah salah satu metode ilmiah/scientific yang telah memenuhi kaidah-kaidah ilmiah yaitu konkrit/empiris, obyektif, terukur, rasional dan sistematis. Dalam penelitian ini peneliti menggunakan desain noneksperimen dan jenis penelitian korelasional. Analisi yang digunakan peneliti adalah regresi linear dengan tujuan untuk mengetahui ada atau tidaknya pengaruh antara kedua variabel.

Populasi dalam penelitian ini adalah pegawai honorer Rumah Sakit. Teknik yang digunakan dalam pengambilan sampel pada penelitian ini menggunakan teknik quota sampling. Quota sampling adalah teknik dalam pengambilan sampel yang memiliki ciriciri tertentu sampai memenuhi jumlah kuota yang diinginkan (Sugiyono, 2011). Margono (2004) menjelaskan bahwa dalam teknik ini diambil dengan memberikan jatah atau jumlah kuota tertentu. Adapun kriteria subjek dalam penelitian ini yang telah ditetapkan antara lain merupakan pegawai honorer, lama bekerja minimal 1 
tahun karena batas minimal menjadi pegawai honorer adalah sudah bekerja selama 1 tahun. Jumlah subjek yang dilibatkan dalam penelitan ini berjumlah total 129 orang pegawai honorer.

Penelitian ini memiliki dua variabel yang akan diteliti yaitu varibel bebas $X$ (independen) dan variabel terikat $Y$ (dependen). Varibel bebas $X$ (independen) dalam penelitian ini adalah resiliensi, dan variabel terikat $Y$ (dependen) adalah job insecurity.

Variabel job insecurity dalam penelitian ini adalah rasa takut atau kekhawatiran, dan ketidakamanan yang dirasakan pegawai/karyawan terhadap masa depan pekerjaannya. Job insecurity sendiri memiliki 2 aspek yaitu kognitif dan afektif (Borg \& Elizur, 1992). Skala JIQ (job insecurity quisionare) disusun berdasarkan tiga komponen penting job insecurity, yaitu: penerimaan subjektif seseorang mengenai pekerjaannya, kekhawatiran terkait fenomena tak terduga, ketidakamanan tentang masa depan (De Witte, 2005 \& Sverke et al, 2004). Pengumpulan data pada alat ukur ini menggunakan Job Insecurity Quisionare yang disusun oleh (De Witte, 2000) berdasarkan teori (Greenhalgh \& Rosenblatt, 1984). Alat ukur tersebut memiliki 11 item yaitu 4 item aspek kognitif dan 7 item aspek afektif. Contoh dari item tersebut adalah "saya merasa khawatir akan karir saya di kemudian hari". Skala yang digunakan berbentuk skala model likert yang terdapat 5 skor total, yaitu (STS) sangat tidak setuju, (TS) tidak setuju, (N) netral, (S) setuju, dan (SS) sangat setuju.

Variabel resiliensi dalam penelitian ini adalah kemampuan inidvidu dalam menghadapi sebuah permasalahan dan bangkit kembali dari kondisi yang menekan dalam hidup dan merubahnya ke arah yang positif. skor total resiliensi didapatkan dari adaptasi alat ukur yang dilakukan oleh Fatimah Azzahra (2016) darialat ukur Connor Davidson - Resilience Scale (CD-RISC) berdasarkan teori (Connor-Davidson, 2003). Skala ini akan diuji kembali oleh peneliti dengan karakteristik subjek penelitian yaitu pegawai honorer, dalam pengukurannya, skala ini diukur menggunakan 5 aspek dari resiliensi yaitu, aspek kompetensi personal, standar tinggi dan keuletan, aspek percaya terhadap diri sendiri dan toleransi terhadap afek negatif, aspek menerima perubahan secara positif dan dapat membuat hubungan yang baik dan aman dengan orang lain, aspek kontrol diri dalam pencapaian tujuan dan bagaimana meminta bantuan kepada orang lain, dan yang terakhir aspek spiritualitas. Skala tersebut berjumlah 25 item dan Tidak memiliki item unfavorable, dengan contoh dari item tersebut adalah "cenderung mampu bangkit kembali setelah mengatasi kesulitan". Skala yang digunakan bermodel skala likert yang terdiri dari 5 skor total, yaitu (STS) sangat tidak setuju, (TS) tidak setuju, (N) netral, (S) setuju, dan (SS) sangat setuju.

Penelitian ini memiliki beberapa tahapan: 1) menentukan fokus permasalahan yang akan di teliti; 2) mencari sumber-sumber pustaka seperti buku, jurnal, dan artikel; 3) menyusun proposal penelitian; 4) melakukan adaptasi dan penyusunan alat ukur yang akan digunakan dan mengukur tingkat validitas dan reliabilitas, kemudian peneliti melakukan adaptasi skala terhadap pegawai honorer di Rumah Sakit.

Tabel 1. Validitas Alat ukur

\begin{tabular}{cccc}
\hline Alat Ukur & Total Item & Total Item Valid & Validitas Alat Ukur \\
\hline CD-RISCH & 25 & 24 & $0,304-0,834$ \\
JIQ & 11 & 10 & $0,264-0,722$ \\
\hline
\end{tabular}


Proses pemilihan beberapa kriteria pada item total biasanya menggunakan batasan $r \geq 0,30$. Azwar (2012) menjelaskan bahwa item minimal mencapai koefisien korelasi sebesar 0,30, akan tetapi bila jumlah item lolos ternyata belum memenuhi jumlah yang diinginkan koefisien korelasi bisa diturunkan menjadi 0,25. Berdasarkan tabel diatas alat ukur penelitian dapat diketahui bahwa dari 25 item skala resiliensi yang di try out terdapat 24 item yang dinyatakan valid setelah diuji secara statistik. Hasil validitas skala resiliensi didapatkan hasil berkisar 0,304 - 0,834. Skala job insecurity memiliki 11 item dan 10 item dinyatakan valid dengan indeks validitas berkisar $0,264-0,722$.

Tabel 2. Reliabilitas Alat Ukur

\begin{tabular}{cc}
\hline Alat Ukur & Hasil Reliabilitas \\
\hline CD-RISCH & 0,896 \\
JIQ & 0,817 \\
\hline
\end{tabular}

Reliabilitas diukur untuk melihat sejauh mana pengukuran tersebut memiliki hasil yang relatif atau tidak berbeda jika dilakukan pada subjek yang sama. Apabila dari alat ukur medapatkan hasil yang jauh berbeda, maka hasil tersebut belum bisa dikatakan reliabel atau tidak dapat dipercaya (Azwar, 2010). Tabel di atas menunjukkan hasil dari kedua alat ukur yang akan digunakan peneliti memiliki reliabilitas diatas 0,60 yang artinya alat ukur layak digunakan untuk mengambil data. Tahap selanjutnya yaitu tahap pelaksanaan. Dalam tahapan ini peneliti akan mengumpulkan data menggunakan alat ukur yang sudah di uji secara validitas dan reliabilitas kepada subjek penelitian yang sudah ditentuka oleh peneliti. Tahap selanjutnya adalah tahap akhir yaitu peneliti menggunakan software IBM SPSS versi 22 dalam menganalisa data, dan pengolahan data dengan melakukan uji regresi linear sederhana untuk mengetahui pengaruh antar variabel.

\section{HASIL}

Tabel 3. Deskripsi Hasil Subjek Peneliti

\begin{tabular}{lcc}
\multicolumn{1}{c}{ KATEGORI } & JUMLAH & PERSENTASE \\
\hline Jenis Kelamin & & \\
Laki-laki & 76 & $59 \%$ \\
Perempuan & 53 & $41 \%$ \\
\hline Usia & & \\
23-29 Tahun & 43 & $33 \%$ \\
30-36 Tahun & 68 & $53 \%$ \\
37-50 Tahun & 18 & $14 \%$ \\
\hline Pendidikan Terakhir & & \\
SMA & 24 & $6 \%$ \\
SMK & 8 & $50 \%$ \\
Diploma & 65 & $25 \%$ \\
S1 & 24 & \\
\hline
\end{tabular}




\begin{tabular}{lcc}
\hline Masa Kerja & & \\
1-4 Tahun & 49 & $38 \%$ \\
5-8 Tahun & 43 & $33 \%$ \\
9-12 Tahun & 37 & $29 \%$ \\
\hline Total & $\mathbf{1 2 9}$ & $\mathbf{1 0 0 \%}$ \\
\hline
\end{tabular}

Tabel 4. Deskripsi Variabel (T-Score)

\begin{tabular}{lcccc}
\hline \multirow{2}{*}{ Variabel } & \multicolumn{2}{c}{ Tinggi } & \multicolumn{2}{c}{ Rendah } \\
\cline { 2 - 5 } & Jumlah & Frekuensi & Jumlah & Frekuensi \\
\hline Job Insecurity & 61 & $47 \%$ & 68 & $53 \%$ \\
\hline Resiliensi & 64 & $49,6 \%$ & 65 & $50,4 \%$ \\
\hline
\end{tabular}

Berdasarkan tabel 4 di atas dapat dilihat bahwa dari 129 pegawai honorer yang sudah dibagi menjadi dua pengkategorian yaitu tinggi dan rendah pada masingmasing variabel. Berdasarkan dari total subjek yang berjumlah 129, sebanyak 61 pegawai honorer masuk dalam kategori job insecurity tinggi dan 68 pegawai honorer masuk dalam kategori job insecurity rendah, pada variabel resiliensi didapati sebanyak 64 pegawai honorer masuk dalam kategori tinggi dan 65 pegawai honorer masuk dalam kategori rendah. Hal ini menunjukan bahwa pegawai honorer memiliki kekhawatiran dan ancaman yang rendah terhadap kelangsungan masa depan pekerjaan dan pegawai honorer juga memiliki kemampuan untuk bangkit kembali dari keterpurukan dan dapat mengubah keadaan yang sulit dan menanggapinya dengan sikap yang positif.

Hasil dari uji normalitas dengan menggunakan analisa One-Sample KolmogorovSmirnov Test (K-S) SPSS Versi 22 diketahui bahwa nilai ke normalan sebesar 0,200 $(>0,05)$ yang artinya dengan analisa menggunakan One-Sample Kolomogorov-Smirnov Test di dapatkan hasil bahwa kedua variabel yaitu $\mathrm{X}$ dan $\mathrm{Y}$ berdistribusi secara normal, dan analisis data selanjutnya akan digunakan untuk mengetahui pengaruh variabel $\mathrm{X}$ dan $\mathrm{Y}$ tersebut adalah uji regresi linear sederhana.

Tabel 5. Nilai Regresi Linear Sederhana

\begin{tabular}{lr}
\hline Koefisien & Nilai Regresi \\
\hline$r$ & 0,306 \\
$r^{2}$ & 0,093 \\
$\beta$ & $-0,252$ \\
$p$ (Nilai Signifikan) & 0,000 \\
\hline
\end{tabular}

Berdasarkan hasil analisa data dengan menggunakan uji regresi linear sederhana diperoleh nilai pada tabel diatas. Korelasi hubungan ( $r$ ) mendapatkan nilai yaitu sebesar 0,306, dan pengaruh variabel bebas terhadap variabel terikat yang disebut $\left(\mathrm{r}^{2}\right)$ mendapatkan nilai 0,093 dari hasil ini resiliensi memberikan pengaruh sebesar 9,3\% terhadap job insecurity dan menunjukan bahwa 90,7\% job insecurity dipengaruhi oleh variabel lain selain resiliensi. $\beta$ sebesar $-0,252$, yang artinya pengaruh variabel resilensi terhadap job insecurity menunjukan arah negatif, jika resiliensi yang dimiliki tinggi 
maka akan rendah job insecurity, dan sebaliknya jika resiliensi yang dimiliki rendah maka akan tinggi job insecurity. Hasil analisa yang telah dilakukan didapatkan bahwa adanya pengaruh yang signifikan pada variabel resiliensi dan job insecurity pada pegawai honorer sebesar $\mathrm{p} 0,000$.

\section{DISKUSI}

Berdasarkan hasil dari penelitian yang telah dilakukan oleh peneliti, diketahui bahwa hipotesis penelitian dapat diterima. Terdapat adanya pengaruh ke arah negatif yang signifikan resiliensi terhadap job insecurity pada pegawai honorer. Resiliensi pada pegawai honorer memberikan pengaruh ke arah negatif pada job insecurity sebesar 0,093 artinya jika resiliensi yang dimiliki tinggi maka akan rendah job insecurity yang dimiliki individu dan begitupula sebaliknya, jika resiliensi yang dimiliki individu rendah maka akan tinggi job insecurity yang dimiliki individu.

Berdasarkan dari hasil penelitian diketahui bahwa hasil penelitian ini sesuai dengan hipotesis yang telah ditetapkan oleh peneliti, yang mana resiliensi memiliki pengaruh ke arah negatif terhadap job insecurity. Hasil dari penelitian ini menunjukan bahwa resiliensi yang tinggi mampu membuat job insecurity rendah. Hasil ini sejalan dengan penelitian yang dilakukan (Leach, 2006), yang menyatakan bahwa resiliensi memiliki hubungan yang signifikan dengan job insecurity dan kesehatan umum pada karyawan perusahan-perusahan di Afrika, secara statistik diketahui bahwa resiliensi memainkan peran moderat dalam hubungan antara job insecurity dan kesehatan umum, yang dimana individu yang memiliki tingkat resiliensi tinggi cenderung kurang terpengaruh terhadap job insecurity dan kesehatan umum.

Berdasarkan dari hasil analisa penelitian, diketahui bahwa adanya pengaruh signifikan dari resiliensi terhadap job insecurity pada pegawai honorer, dalam hal ini pegawai honorer khususnya perawat memiliki karakteristik kerja yang berbeda dengan pegawai/karyawan lainnya. Pegawai honorer khususnya perawat sebagian besar waktunya bertemu dengan pasien dibandingkan dengan pegawai honorer lainnya atau tenaga kesehatan yang bukan perawat (Hardani, 2016). Digdyani \& Veronika (2018) mengatakan dalam penelitiannya bahwa resiliensi memiliki pengaruh kepada semua dimensi kualitas hidup yang dimiliki tenaga kesehatan, pegawai honorer khususnya perawat yang memiliki resiliensi akan menjadikan pekerjaanya yang dijalani manjadi sebuah semangat (passion) dan merasa pekerjaanya sangat dibutuhkan oleh masyarakat.

Pegawai honorer pada penelitian ini memiliki resiliensi yang tinggi karena menurut (Connor \& Davidson, 2003) resiliensi memiliki kompetensi personal, dan percaya terhadap diri sendiri, hal ini akan membuat pegawai honorer menganggap suatu pekerjaan adalah hal yang sangat penting dan tidak akan merasa khawatir akan kelangsungan pekerjaannya di masa yang akan datang. Rendahnya job insecurity berkaitan dengan persepsi individu dalam menginterpretasikan pekerjaannya di masa depan (Probst, 2008), situasi lingkungan dapat menghasilkan respon sikap yang berbeda pada setiap pegawai.

Resiliensi yang tinggi dapat membuat pegawai honorer berusaha dalam mencapai tujuannya, karena pegawai dapat mengontrol diri mereka dan fokus pada pekerjaannya. Pegawai honorer yang memiliki kinerja baik bisa membuat mereka 
mudah mendapatkan penghargaan ataupun respon yang baik (positif) dari instansi tempatnya bekerja. Hal ini yang dapat membuat pegawai honorer merasa puas dalam pekerjaannya serta memiliki keinginan untuk tetap dapat bekerja dan menganggap bahwa aspek pekerjaan lainnya juga sangat penting seperti kompensasi dan lingkungan kerja yang baik dapat mempengaruhi tingkat keamanan dan kenyamanan seorang inividu ketika bekerja (Rahmawati et al, 2013). Resiliensi dan komitmen organisasi yang dimiliki oleh pegawai honorer juga mempengaruhi pada kebermaknaan kerja (meaningful work). Resiliensi tinggi yang dimiliki pegawai honorer dapat membuat komitmen dalam bekerja semakin tinggi, hal ini disebabkan karena pegawai honorer memiliki kebermaknaan kerja yang positif, dan membuat individu mampu dalam memahami setiap aspek dalam pekerjaan.

Hasil dari penelitian ini terbukti bahwa resiliensi memiliki pengaruh yang signifikan terhadap job insecurity, dan job insecurity pada pegawai honorer tergolong rendah. Hal ini terjadi karena pegawai honorer rata-rata bekerja lebih dari 1 tahun, dari data subjek penelitian didapatkan 38\% atau 49 subjek dari total 129 subjek yang terlibat dalam penelitian ini yang sudah mencapai masa kerja 1-4 tahun, $33 \%$ atau 43 subjek lainya telah mencapai masa kerja 5-8 tahun, dan $29 \%$ atau 37 subjek telah mencapai masa kerja 9-12 tahun. Hal ini menunjukan bahwa semakin lama masa kerja maka semakin rendah pemicu munculnya job insecurity pada individu.

Hasil penelitian ini didapatkan skor rendah pada job insecurity yaitu sebanyak 61 orang (47\%), dari hasil ini menunjukkan bahwa pegawai honorer memiliki tingkat job insecurity yang rendah. Hasil skor pada resiliensi didapatkan sebanyak 64 orang atau $49,6 \%$ berada pada skor tinggi. Resiliensi yang tinggi akan mempengaruhi efikasi pegawai, (Adebayo, 2006) mengatakan bahwa efikasi mampu membantu pegawai/karyawan memberikan respon positif ketika dihadapkan pada situasi yang menekan dalam pekerjaanya. Berdasarkan dari-data yang didapatkan pegawai honorer memiliki masa kerja yang cukup lama .Hal ini dikarenakan pegawai yang memiliki rasa optimis yang tinggi dapat membantu dirinya mengatasi job insecurity dalam pekerjaannya. Bosman et al (2005) dalam penelitiannya menerangkan mengenai karakteristik orang dengan optimisme yang tinggi mampu melihat pengalamanpengalaman stres dari sudut pandang yang positif. Hasil dari penelitian ini juga didapatkan 65 pegawai hoonorer memiliki resiliensi yang rendah, rendahnya resiliensi pada pegawai honorer disebabkan oleh faktor yang kurang mendukung terbentuknya resiliensi seperti spiritualias rendah, kurang merasa optimis pada pekerjaan, memiliki kontrol diri yang rendah, dan kurang mampu menyelesaikan masalah dengan tenang.

Berdasarkan hasil dari penelitian ini menunjukkan bahwa pegawai honorer memiliki resiliensi tinggi dengan memberikan pengaruh kearah negatif yang signifikan pada job insecurity sebesar 9,3\% sedangkan 90,7\% dipengaruhi oleh faktor lain seperti kondisi lingkungan dan organisasi, krakteristik jabatan, karakteristik personal pekerjaan seperti locus of control, dan self esteem (Ashford et al, 1989).

\section{SIMPULAN DAN IMPLIKASI}

Berdasarkan hasil penelitian yang telah dilakukan peneliti terhadap 129 pegawai honorer dapat disimpulkan bahwa terdapat adanya pengaruh signifikan ke arah negatif resiliensi terhadap job insecurity dimana semakin tinggi resiliensi pegawai 
honorer maka semakin rendah job insecurity dan sebaliknya jika semakin rendah resiliensi pegawai honorer maka akan tinggi job insecurity. Hasil penelitian ini terbukti bahwa resiliensi memberikan pengaruh sebesar 9,3\%, sedangkan 90,7\% dipengaruhi oleh faktor lain seperti kondisi lingkungan dan organisasi, karakteristik jabatan, karakteristik personal jabatan, locus of control, self esteem, efikasi diri, optimisme dan lain-lain.

Implikasi dari penelitian bagi Instansi/Perusahaan yang bergerak khususnya di bidang pelayanan masyarakat diharapkan terus meningkatkan resiliensi para pegawainya agar dapat memberikan kinerja yang profesional dan mengurangi tingkat job insecurity, dan diharapkan peneliti selanjutnya kedepannya dapat dilakukannya penelitian yang serupa dengan variabel lain yang mempengaruhi job insecurity, semoga penelitian ini dapat memberikan informasi dan gambaran terkait pengaruh resiliensi terhadap job insecurity.

\section{REFERENSI}

Adebayo, D. O. (2006). The moderating effect of self-efficacy on job insecurity and organisational commitment among Nigerian public servants. Journal of Psychology in Africa, 16(1), 35-43.

Andrinirina, M. (2015). Pengaruh Job Environment dan Job Insecurity Terhadap Kinerja dan Turnover intention Karyawan pada Royal Hotel n'Lounge. Jember; Universitas Jember

Ashford, S.J., C. Lee, \& P. Bobko. (1989). Content,Causes, and Consequences of Job Insecurity; A Theory Based Measure and Substantive Test, Academy of Management Journal ,32 (4): 803-829.

Azwar, S. (2010). Reliabilitas dan Validitas. Yogyakarta: Pustaka Pelajar Offset

Azwar, S. (2012). Metode Penelitian. Yogyakarta: Pustaka Belajar

Azzahra, Fatimah. (2016). Pengaruh Resiliensi terhadap Distres Psikologi pada Mahasiswa. Malang; Universitas Muhammadiyah Malang

Bitsika, et al. (2010).How is resilience associated with anxiety and depression?Analysis of factor score interactions within a homogeneous sample. The German Journal of Psychiatry

Borg, I., Elizur, D. (1992). Job Insecurity: Correlates, Moderators, and Measurement. International Journal of Manpower. 13 (2), 13.

Bosman, J., Buitendach, J.H., \& Rothman, S. (2005). Work locus of control and dipositional optimism as antecedents to job insecurity. SA Journal of Industrial Psychology, 31(4), 1723.

Chirumbolo, Antonio. (2005). The Influence Of Job Insecurity On Job Performance and Absenteeism; The Moderating Effect Of Work Attitude

Connor \& Davidson. (2003). Psychometric Analysis and Refinement of the Connor-Davidson Resilience Scale (CD-RISC) : Validation of a 10-item Measure of Resilience Journal of Traumatic Stress.Vol 20, No. 6, December 2007

Coulson, R. (2006). Resilience and self-talk in. Thesis. University Students: University of Calgary

De Cuyper, N., Bernhard-Oettel, C., Bemtson, E, De Witte, \& Alarco, B. (2008).Employability and employees well-being: mediation by job insecurity. Applied Psychology an International Review, 57(3), 488-509

Detik.com. (2018). Pegawai Honorer di Indonesia. Diakses ada tanggal 4 Oktober 2018. http://detik.com

Dewanti, A. P., \& Suprapti, V. (2014).Resilensi Remaja Putri terhadap Prolematika Pasca Orang Tua Bercerai. Jurnal Psikologi dan Perkembangan. Vol 3, No. 3. 
De Witte, H, \& Cuyper, N. (2005). Job Insecurity: Mediator or Moderator of the Relationship Between Type of Contract and Various Outcomes? Journal of Industrial Psychology. 31 (4), 79-86

De Witte, H, \& Naswall, K. (2003). Objective vs Subjevtive Job Insecurity Consequences of Temporary Work for Job Satisfaction and Organizational Commitment in four European Countries.Economic and Industrial Democracy, 24, 149-188

Digdyani, N, \& Veronika, D. (2018). Hubungan Antara Regulasi Diri dan Resiliensi Dengan Kualitas Hidup Pada Perawat Rumah Sakit Swasta X Di Kota Semarang. Jurnal Empai. Vol 7. No. 3. Hal 179-185

Dipayanti, S., \& Chairani, L. (2012). Locus of Control dan Resiliensi pada Remaja yang Orang Tuanya Bercerai. Jurnal Psikologi, Vol. 8. No. 1, Juni 2012.

Elst, T.V., De Witte, H, \& De Cuyper, N. (2014). The Job Insecurity Scale; Psychometric Evaluation across five European Countries.European Journal of Work and Organizational Psychology, 23(3), 364-380

Ermawan, D. (2007). Hubungan antara Job Insecurity dan Konflik Peran terhadap Komitmen Organisasi. Skripsi. Surakarta; Universitas Muhammadiyah Surakarta

Farida, Y. N. (2003). Pengaruh Job Insecurity dan Kompensasi Terhadap Kepuasan Kerja. Empirika.Vol. 16, No. 1, Hal. 126-148

Fredrickson, B. L., \& Feldman Barrett, L. (2004). Psychological resilience and positive emotional granularity: Examining the benefits of positive emotions on coping and health. Journal of personality, 72(6), 1161-1190.

Garmezy, N. (1996) "Reflections and commentary on risk, resilience, and development". Stress, risk, and resilience in children and adolescents: Processes, mechanisms, and interventions: 1-18.

Grotberg, E. (1999). Countering Depression with The Five Building Blocks of Resilience. Article

Greenhalgh, L \& Rosenblatt, Z. (1984). Job Insecurity; Toward Conceptualclarity. Academy of Management Review 9(1) 438-448

Hardani. (2016). Stres kerja dan kepuasan kerja dengan kualitas hidup Perawat icu di rs tipe B, Journal Endurance,1(3) , 113-120.

Holaday \& McPhearson. (1997). Resilience and Severe Burns. Journal of Counseling and Development : 75, 5 .

International Labour Organization (2015, November). Tren Sosial Ketenagakerjaan (terbaru). Jakarta: Tim Penulis

Klandermans, B., \& van Vuuren, T. (1999). Job insecurity. European Journal of Work and Organizational Psychology, 8 (2), 145 -314.

Kurniasari, L. (2005). Pengaruh komitmen organisasi dan job insecurity karyawan terhadap intensi turnover. http://www.damandiri.or.id/file/luvikurniasariunairbab2.pdf. Diakses pada tanggal 26 Maret 2007 pukul11.30

Leach, R. J. (2006). Job Insecurity, Resilience and General Health of Motor-Trade Employee. Thesis. America; American Psychological Association.

Listyanti, E., W. (2012). Regulasi Emosi dan Resiliensi pada Mahasiswa Tahun Pertama. Jurnal Humanitas, Vol. IX. No. 2, Agustus 2012.

Margono. (2004). Metodologi Penelitian Pendidikan. Jakarta: PT Rineka Cipta.

McCubbin, L. (2001). Challenges to the Definition of Resilience. Journal of Development and Psychopathology, 5, 497-502.

Nuraini, A. A. (2017). Hubungan Resiliensi dengan Job Insecurity dan komitmen organisasi pada karyawan kontrak. Skripsi. Malang; Universitas Muhammadiyah Malang

Olsson, C. A., Bond, L., Burns, J. M., Vella-Brodrick, D. A., \& Sawyer, S. M. (2003). Adolescent resilience: A concept analysis. Journal of adolescence, 26(1), 1-11. 
Pasewark, W.R. \& Strawser, J.R. (1996). “The Determinants and Outcomes Associated With Job Insecurity in a Professional Accounting Environment". Journal of Behavioral Research in Accounting. Vol. 8. pp. 91-110.

Pillay, S. (2006). The Relationship between job insecurity, Job Satisfaction and Organisational Commitment In aTelecommunication Organisation. South Africa; University of KwaZulu-NatalIndustri dan Organisasi. Vol. 1 No. 02

Rahmawati, A., Chishaki, A., Sawatari, H., Tsuchihashi-Makaya, M., Ohtsuka, Y., Nakai, M., \& Mukai, Y. (2013). Gender disparities in quality of life and psychological disturbance in patients with implantable cardioverter-defibrillators. Circulation Journal, CJ-12.

Rakayoga, Lanang, G. (2014). Civil service Discipline Based On The Government Regulation Number 53 Year 2010 Viewed From The Personel Law Aspect In Indonesia. Jurnal IUS (Kaian Hukum dan Keadilan) 2.2,hal 328

Reivich, K. \& Shatte, A. (2002). The resiliency factor: 7 key to finding your inner streght and overcoming life's hurdles. New York: The Guidfor press.

Ridwan, Arifani. (2016). Locus of Control dan Resiliensi pada Pekerja yang Mengalami Pemutusan Hubungan Kerja (PHK). Skripsi. Malang; Universitas Muhammadiyah Malang

Riley, J. R., \& Masten, A. S. (2005). Resilience in children, families, and communities: Linking context to practice and policy. New York, NY: Kluwer Academic/Plenum.

Riza, Muhammad, \& Ike, Herdiana. (2013). Resiliensi pada narapidana laki-laki di lapas klas 1 Medaeng. Jurnal Psikolog Kepribadian dan Sos 2.01: 1-6.

Robbins, S. (2003). Perilaku Organisasi, Jakarta; PT Indeks Kelompok Gramedia

Schoon, Ingrid. (2006). Risk and Resilience. New York; Cambridge University Press

Shoss, M. K., Jiang, L., \& Probst, T. M. (2018). Bending without breaking: A two-study examination of employee resilience in the face of job insecurity. Journal of occupational health psychology, 23(1), 112.

Smithson, Janet., Suzan Lewis. (2000). Is Job Insecurity Changing the Psychological Contract. Personel Review, 29(6); 1-15

Sugiarti. (2006). Hubungan antara Kepuasan Kerja dengan Job Insecurity pada Guru Negeri dan Guru Swasta. Skripsi. Surakarta: Fakultas Psikologi Universitas Muhammadiyah Surakarta

Sugiyono. (2011). Metode Penelitian Kuantitatif, Kualitatif, dan R\&D. Bandung : Alfabeta

Sugiyono. (2012). MetodePenelitian Pendidikan (Pendekatan Kuantitatif, Kualitatif, dan R\&D). Bandung : Alfabeta

Sukmaningrum, R, D. (2018). Hubungan Antara Employability dan Job Insecurity pada Karyawan Kontrak di Perusahaan Swasta. Yogyakarta: Fakultas Psikologi Universitas Sanata Dharma Yogyakarta

Sverke, M., Hellgren, J. (2002). The Nature of Job Insecurity; Understanding employment uncertainty on the brink of a new millennium. Journal Applied Psychology. Vol. 31 no. 2 $175-178$

Thoha, M. (2005). Manajemen kepegawaian sipil di Indonesia. Jakarta; Prenada Media.

Van Vuuren. (1999). Job flexibility and job insecurity: The Dutch Case. European Journal of Work and Organizational Psychology, $8: 273-293$

Werner, Emmy, E. (2005). Resilience and Research : Past, Present, and Future. New York : Plenum Publisher.

Yashoglu, Murat dkk. (2013). An Empirical Research on the Relationship between Job Insecurity, Job Related Stress and Job Satisfaction in Logistics Industry. Procedia - Social and Behavioral Sciences 99 : $332-338$ 


\section{JOB INSECURITY, RESILIENCE, HONORARY EMPLOYEES}

Yuniar, I Gusti Agung Yesika dkk. (2011). Hubungan antara kepuasan kerja dan resiliensi dengan OCB pada karyawan kantr pusat PT.BPD Bali. Jurnal Psikologi Undip : Vol.9 No. 1 